Atmos. Chem. Phys. Discuss., https://doi.org/10.5194/acp-2017-554

Manuscript under review for journal Atmos. Chem. Phys.

Discussion started: 5 July 2017

(c) Author(s) 2017. CC BY 4.0 License.

\title{
Significant Seasonal Change in Optical Properties by atmospheric humic-like substances (HULIS) in Water-Soluble Organic Carbon Aerosols
}

\author{
Heejun $\mathrm{Han}^{1}$, Guebuem Kim ${ }^{1}$ \\ $5{ }^{1}$ School of Earth and Environmental Sciences/RIO, Seoul National University, Seoul 08826, Korea \\ Correspondence to: Guebuem Kim (gkim@snu.ac.kr)
}

Abstract. Atmospheric humic-like substance (HULIS) is an important fraction of water-soluble organic carbon (WSOC) accounting for the light-absorbing properties of organic aerosols. HULIS is responsible for light-absorbing properties of organic aerosols in the atmosphere. Although various sources of HULIS have been studied extensively, its sinks are poorly constrained. In this study, we found seasonal changes in the optical and chemical characteristics of HULIS and WSOC, which are decreased by approximately $80 \%$ and $30 \%$, respectively, from the cold season (Oct-Jan) to the warm season (Jun-Sep) due to enhanced solar ultraviolet (UV) radiation. The dominant role of photochemical degradation on lightabsorbing organic aerosols, as a sink of HULIS, was further confirmed based on a laboratory experiment by evaluating impact of UV radiation on the optical properties of HULIS and WSOC contents. Our results suggest that seasonal variation of HULIS in WSOC is resulted mainly by photo-induced degradation in the atmosphere. Thus, photochemical degradation of HULIS seems to play a critical role on seasonal variations in the light-absorbing properties of organic aerosols as well as the biogeochemical impact of WSOC on Earth's surface.

\section{Introduction}

Organic aerosols play a significant role in atmospheric chemistry, global biogeochemical cycles, air quality, and the climate system on Earth (Kirillova et al., 2014a; Duarte and Duarte, 2013; Ghan and Schwartz, 2007). A major fraction of organic aerosols is made up of water-soluble organic carbon (WSOC), which contributes $10-80 \%$ of the total organic carbon aerosols (Kirillova et al., 2014a; Kirillova et al., 2014b; Fu et al., 2015). The WSOC is currently known to contain a lightabsorbing organic carbon called brown carbon (BrC) (Kirillova et al., 2014a; Kirillova et al., 2014b; Graber and Rudich, with a substantial portion (Fu et al., 2015; Graber and Rudich, 2006; Andreae and Gelencser, 2006).

Recently, the light-absorbing organic aerosols including $\mathrm{BrC}$ and HULIS have received growing attention due to its 

and Gelencser, 2006; Graber and Rudich, 2006; Saleh et al., 2014; Ramanathan et al., 2007) and by acting as cloud condensation nuclei (CCN) for cloud formation (Kirillova et al., 2014a; Andreae and Gelencser, 2006; Graber and Rudich, 2006; Kanakidou et al., 2005). It has been found that there is a significant overlap in the light-absorbing properties and chemical compounds between BrC and HULIS (Andreae and Gelencser, 2006; Graber and Rudich, 2006; Hoffer et al., 2006). Both BrC and HULIS are known to originate from biomass burning, incomplete combustion process, secondary formation, and soil humics (Andreae and Gelencser, 2006; Graber and Rudich, 2006; Hoffer et al., 2006; Ramanathan et al., 2007; Kivácsy et al., 2008; Saleh et al., 2014). Although the light-absorbing properties of $\mathrm{BrC}$ and HULIS are expected to be weaker than those of black carbon (BC), which absorbs a wide range of spectra from visible to near-infrared radiation, their contribution would be significant due to its higher abundance in the atmosphere (Hoffer et al., 2006; Gustafsson et al., 2009).

However, current understanding of the optical properties, chemical composition, and atmospheric processes of the lightabsorbing organic aerosols still remain uncertain and controversial. Thus, we evaluated seasonal changes in the optical and chemical characteristics of organic aerosols in order to determine the sources and sinks of HULIS and WSOC in Seoul, Korea. Previous studies have suggested that absorbance and fluorescence property of organic matter are closely interrelated each other in their compounds and optical properties (Green and Blough, 1994; Kieber et al., 2006; Mladenov et al., 2010; Santos et al., 2009). Recently, the method of excitation-emission matrix (EEM) characterization combined with parallel factor analysis (PARAFAC) model has been implemented for atmospheric HULIS in several studies (Kieber et al., 2006; Mladenov et al., 2011; Matos et al., 2015; Chen et al., 2016; Xie et al., 2016). This unique multi-analysis method is applied to identify individual fluorescent groups of sample solutions as HULIS index in the present study (Bro, 1997; Stedmon and Bro, 2008; Mladenov et al., 2011; Kieber et al., 2006; Birdwell and Engel, 2010; Coble, 2007). Also, we measured stable carbon isotope ratio of WSOC $\left(\delta^{13} \mathrm{C}_{\mathrm{WSOC}}\right.$ ) (Kirillova et al., 2014a; Kirillova et al., 2014b; Fu et al., 2015; Kelly et al., 2005; Bosch et al., 2014) and various chemical constituents in aerosol samples over different seasons. In addition, we conducted a laboratory experiment to examine the impact of ultraviolet (UV) radiation on optical properties and carbon composition of HULIS and WSOC.

\section{Experimental methods}

\subsection{Study site and sample collection}

Seoul is a capital city of South Korea and one of the largest metropolitan cities in the world. Korea has been highly affected

by severe dust storms called the Asian dust or the Yellow dust originated mostly from the Chinese and Mongolian deserts 
Atmos. Chem. Phys. Discuss., https://doi.org/10.5194/acp-2017-554

Manuscript under review for journal Atmos. Chem. Phys.

Discussion started: 5 July 2017

(c) Author(s) 2017. CC BY 4.0 License.

(c) (i)

during the month of spring (Mar-May) and often during the winter (Dec-Jan) (Lin et al., 2012). Asian dust, which is a seasonal or annual meteorological phenomenon in East Asia, travels all over China and drives across South Korea to Japan characterized with a period of high aerosol loading (Chun et al., 2001). Recently, the Asian fine dust-derived air pollution is mostly concerned and a focus of major environmental issue with highly increased anthropogenic emissions.

5

Aerosol samples $(N=78)$ were collected using a high volume air sampler (HV-1000, SHIBATA) from March 2015 to January 2016 in Seoul, Korea (37.5 N, $127^{\circ}$ E; 20 m a.g.l.) (Fig. 1). Samples were collected for $24 \mathrm{~h}$ at a constant flow rate of $1000 \mathrm{~L} \mathrm{~min}{ }^{-1}$ through a pre-combusted $\left(450{ }^{\circ} \mathrm{C}\right.$ for $\left.5 \mathrm{~h}\right)$ glass microfiber filter $(\mathrm{GF} / \mathrm{F}, 8 \times 10 \mathrm{inch}, 2 \mu \mathrm{m}$ pore size, Whatman). The total air volume of samples was averaged to $1440 \mathrm{~m}^{3}$, and in situ measurement of pressure and temperature were recorded. Blank sample was collected by exposing a blank filter briefly at the study site and analyzed in the same way to other aerosol filter samples. Total suspended particulates (TSP) of aerosol sample were measured using mass differences of desiccated filters between pre- and post-sampling. Collected samples were covered with aluminum foil, placed in polyethylene bag, and store in the dark at $-20^{\circ} \mathrm{C}$ until the analysis.

Such parameters including temperature, UV radiation rate, precipitation rate, and daily records of atmospheric particulate matters $\mathrm{PM}_{10}$ and $\mathrm{PM}_{2.5}$, which are a mixture of fine solid particles with aerodynamic diameters less than or equal to 10 and $2.5 \mu \mathrm{m}$, of the study site were obtained from the ambient air quality monitoring network named AirKorea in Korea Environmental Corporation (KECO) and Korea Meteorological Administration (KMA).

In addition, total PM concentration of the study site $\left(\mathrm{PM}_{\mathrm{T}}\right)$ was calculated using the mass of TSP and total air volume collected during sampling period to verify the regional representativeness of aerosol samples collected in the study site. The concentration of total $\mathrm{PM}_{\mathrm{T}}$ was compared with the $\mathrm{PM}_{10}$ concentrations of other provinces in Korea provided from KECO and KMA (Fig. S1). A good correlation between $\mathrm{PM}_{\mathrm{T}}$ and $\mathrm{PM}_{10}$ concentrations $\left(\mathrm{r}^{2}>0.5\right)$ was found in several different regions in Korea. The most significant correlation $\left(\mathrm{r}^{2}=0.7\right)$ was found with the $\mathrm{PM}_{10}$ concentration recorded at the Seoul monitoring station, which is the nearest station to the study site. The PM correlation data of aerosol sample collected in the study site was fully representative of geographical region around the study site, which may covers regional characteristics of northeastern Asia.

\subsection{Air mass back trajectory}


Atmos. Chem. Phys. Discuss., https://doi.org/10.5194/acp-2017-554

Manuscript under review for journal Atmos. Chem. Phys.

Discussion started: 5 July 2017

(c) Author(s) 2017. CC BY 4.0 License.

(c) (i)

Atmospheric

Chemistry

and Physics

Discussions

A 10-day air mass back trajectory has been analyzed using the Hybrid Single-Particle Lagrangian Integrated Trajectory (HYSPLIT) model to determine the source regions and transport pathways of air masses to the study site (Fig. 1) (Stein et al., 2015). Due to a regional meteorology of the study site, which is dominated by the East Asian Monsoonal effect, most air masses are transported from the arid and semi-arid regions in the Asian continent where the Yellow dusts are blowing from

5 especially during the spring (Mar-Apr) and often in winter (Nov-Jan). According to the trajectory model, almost all air masses in spring, fall, and winter were transported from the northeastern provinces of China, which accounted for approximately $64 \%$ of the total air masses to the study site (Fig. 1). During the summer (Jul-Aug), most air masses were transported from near surrounding oceans of South Korea: the Yellow Sea, the South Sea, and the East Sea.

\subsection{Aerosol extraction and chemical analyses}

For the analyses of aerosol water-soluble organic materials, a small portion of filter paper $\left(18 \mathrm{~cm}^{2}\right)$ was cut into small pieces $(1 \times 1 \mathrm{~cm})$ and placed in a pre-HCl rinsed bottle. The sample was subjected to extraction using deionized (Milli-Q) water $(18.2 \mathrm{M} \Omega \mathrm{cm}$ ) and placed in the shaker table for $4 \mathrm{~h}$ at $125 \mathrm{rpm}$ (Wozniak et al., 2012). The extracted solutions were filtered through a syringe filter $(0.45 \mu \mathrm{m}$ pore size Nucleopore, Whatman) and analyzed for WSOC and total dissolved nitrogen (TDN) by a high temperature oxidation method using a total organic carbon (TOC) analyzer (TOC- $\mathrm{V}_{\mathrm{CPH}}$, Shimadzu). Major ion species $\left(\mathrm{NO}_{\mathrm{X}}, \mathrm{NH}_{4}{ }^{+}, \mathrm{SO}_{4}^{-2}, \mathrm{Ca}^{2+}\right.$, and $\mathrm{K}^{+}$) were analyzed using high performance liquid chromatography (HPLC) (Waters 2695 system) equipped with a conductivity detector (Waters 432) (Yan and Kim, 2015). Water-soluble organic nitrogen (WSON) concentration was calculated using the difference between TDN and the sum of inorganic nitrogen species $\left(\mathrm{NO}_{2}{ }^{-}\right.$, $\mathrm{NO}_{3}^{-}$, and $\mathrm{NH}_{4}^{+}$). The sea-spray fraction was calculated using $\mathrm{Cl}^{-}$and $\mathrm{Na}^{+}$concentrations assuming that all $\mathrm{Cl}^{-}$and $\mathrm{Na}^{+}$ originated from seawater: sea-spray $=\mathrm{Cl}^{-}+1.4468 \mathrm{Na}^{+}$(Maenhaut et al., 2008). The blank corrections were made using the WSOC measurement of blank filter (Kirillova et al., 2014b; Wozniak et al., 2012).

\subsection{Stable carbon isotope ratio measurement}

The stable carbon isotope ratio of WSOC $\left(\delta^{13} \mathrm{C}_{\mathrm{WSOC}}\right)$ was measured using an isotope ratio mass spectrometer (IRMS) (Isoprime, Elementar) combined with TOC analyzer (Vario TOC cube analyzer, Elementar) (Kim et al., 2015). Sample solutions were injected into the TOC analyzer for the high temperature combustion method to measure $\mathrm{CO}_{2}$ using a nondispersive infrared sensor (NDIR) detector and continuously flowed through a reduction column inside of an interface to IRMS (Panetta et al., 2008; Troyer et al., 2010). The isotopic composition $\delta^{13} \mathrm{C}_{\mathrm{WsOC}}$ was determined using the following Eq. (1): 
Atmos. Chem. Phys. Discuss., https://doi.org/10.5194/acp-2017-554

Manuscript under review for journal Atmos. Chem. Phys.

Discussion started: 5 July 2017

(c) Author(s) 2017. CC BY 4.0 License.
Atmospheric

Chemistry

and Physics

Discussions

$\delta^{13} C=\left(\frac{\left({ }^{13} C /{ }^{12} C\right)_{\text {sample }}}{\left({ }^{13} C /{ }^{12} C\right)_{\text {Standard }}}-1\right) \times 1000 \%$

where Vienna Pee Dee Belemnite (VPDB) was used as the isotope standard (Troyer et al., 2010; Fu et al., 2015; Kelly et al., 2005). Analytical tests were conducted with IAEA-CH6 sucrose $\left(\delta^{13} \mathrm{C}=-10.45 \pm 0.03 \%\right)$ and Suwannee River Fulvic Acid (SRFA) $\left(\delta^{13} \mathrm{C}=-27.6 \pm 0.12 \%\right.$; International Humic Substances Society) to evaluate recovery yields as well as the accuracy and precision of the measurements (Panetta et al., 2008; Troyer et al., 2010).

\subsection{Optical characteristics}

EEM spectroscopy was measured using a spectrofluorometer (FS-2, SCINCO). The emission and excitation wavelength ranges were set from 250 to $600 \mathrm{~nm}$ with $2 \mathrm{~nm}$ scanning intervals and from 250 to $500 \mathrm{~nm}$ with $5 \mathrm{~nm}$ scanning intervals, respectively. The fluorescence intensities were normalized using the values of a quinine sulfate dihydrate (QS) standard solution at the excitation/emission wavelength of 350/450 nm in a quinine sulfate unit (QSU) (Velapoldi and Mielenz, 1980). The QS standard solution was made using a quinine stock solution diluted in $0.1 \mathrm{~N}$ sulfuric acid. Raman and Rayleigh scattering signals were removed, and the results were validated by split-half and random initialization analyses (Bro, 1997; Stedmon and Bro, 2008; Zepp et al., 2004).

The PARAFAC model was performed in the MATLAB R2013a program using the DOMFluor toolbox in order to determine the fluorescent components in WSOC (Stedmon and Bro, 2008; Kim and Kim, 2016). The number of unique components was identified from the combined EEM data of aerosol samples and the results were validated by split-half analysis and analysis using random initialization (Stedmon and Bro, 2008).

Absorbance spectra for the laboratory experimental results were obtained by Aqualog Horiba spectrometer, which measures both absorbance and fluorescence EEM. Absorption was measured throughout the UV and visible spectrum (240-600 nm), and specific absorption values at $240 \mathrm{~nm}$ and $350 \mathrm{~nm}$ were measured at the respective wavelength. For the fluorescence measurements, emission and excitation wavelength ranges were set from 250 to $600 \mathrm{~nm}$ and from 250 to $500 \mathrm{~nm}$, respectively, with $5 \mathrm{~nm}$ scanning intervals. The entire HULIS signal of aerosol EEM was integrated for comparison (Kieber et al., 2006). EEMs were normalized with Raman peak area of water and stated as Raman Unit (RU) (Lawaetz and Stedmon, 2009). Inner-filter correction and blank subtraction were performed with Aqualog software. 
Atmos. Chem. Phys. Discuss., https://doi.org/10.5194/acp-2017-554

Manuscript under review for journal Atmos. Chem. Phys.

Discussion started: 5 July 2017

(c) Author(s) 2017. CC BY 4.0 License.

(c) (i)

\subsection{Photochemical degradation experiment}

Laboratory experiment was conducted using a small portion of aerosol filter sample inside of the incubator equipped with internal UV lamp (UV-B; 280-315 nm; $15 \mathrm{~W}$ ) during a 6-week treatment. The incubator was maintained under positive air pressure with a constant temperature at $20^{\circ} \mathrm{C}$. Two comparative aerosol filter samples were selected randomly from each of the higher and lower fluorescent groups, which had a similar range of WSOC concentration (summer $=15.7 \mu \mathrm{mol} \mathrm{L}^{-1}$; winter $=18.7 \mu \mathrm{mol} \mathrm{L}^{-1}$ ). Each aerosol filter was directly exposed to the stimulated UV radiation from $1 \mathrm{~d}$ to $42 \mathrm{~d}$. Each of the nonirradiated aerosol samples was evaluated for the initial measurements. The photochemical degradation of fluorescent WSOC was evaluated by measuring changes in the residue. Each sample was analyzed using spectrometers (FS-2, SCINCO; Aqualog, Horiba) and TOC analyzer after the UV exposure.

\section{Results and discussion}

\subsection{Fluorescence property of HULIS}

The PARAFAC model identified two humic-like fluorescent components and one protein-like fluorescent component in aerosol WSOC (Fig. S2) (Birdwell and Engel, 2010; Coble, 2007). The spectral characteristics of component 1 (C1; Ex/Em $=305 / 416 \mathrm{~nm})$ refer to humic substances, which are assigned to peak $\mathrm{M}$, while component $3(\mathrm{C} 3 ; \mathrm{Ex} / \mathrm{Em}=365 / 484 \mathrm{~nm})$ is associated with terrestrial humic substances, which are assigned to peak C (Table S1) (Birdwell and Engel, 2010; Coble, 2007). Component $2(\mathrm{C} 2 ; \mathrm{Ex} / \mathrm{Em}=290 / 340 \mathrm{~nm})$ represents a protein-like (tryptophan-like) component, which is assigned to peak $\mathrm{T}$ and is mostly originated from autochthonous biological production (Table S1) (Birdwell and Engel, 2010; Coble, 2007; Kim and Kim, 2016). However, C2 and C3 seem to be highly influenced by the most abundant and dominant

fluorophore $\mathrm{C} 1$ because of its high intensity and large spectral area compared to other two components. In addition, strong linear correlations between $\mathrm{C} 1$ and $\mathrm{C} 2\left(\mathrm{r}^{2}=0.8\right)$ and between $\mathrm{C} 1$ and $\mathrm{C} 3\left(\mathrm{r}^{2}=0.9\right)$ was found in aerosol samples (Fig. S3). Thus, we used $\mathrm{C} 1$ as an index of atmospheric HULIS in this study.

\subsection{Seasonal variation}

The WSOC concentrations showed seasonal variation ranging from 3 to $40 \mu \mathrm{g} \mathrm{m}^{-3}$ (mean $=16 \pm 7 \mu \mathrm{g} \mathrm{m}^{-3}$ ) with higher values during the cold seasons (Oct-Jan) (mean $=18 \pm 7 \mu \mathrm{g} \mathrm{m}^{-3}$ ) and relatively lower values during the warm seasons (Jun-Sep) $\left(\right.$ mean $\left.=13 \pm 3 \mu \mathrm{g} \mathrm{m}^{-3}\right)$ (Fig. 2a). This result is consistent with seasonal trends observed by Xie et al. at high elevation remote site (Xie et al., 2016). The fluorescence intensity of HULIS (C1) exhibited a similar seasonal variation, which is consistent with WSOC, ranging from 4.5 to 289 QSU (mean $=64 \pm 53$ QSU) (Fig. 2b). In order to normalize the fluorescence intensity 
of HULIS against the abundance of total water-soluble organic aerosols, HULIS intensity was normalized to the WSOC content. The seasonal trend of HULIS to WSOC ratios was also similar to that of HULIS, indicating that there is pronounced decrease of the average fraction of HULIS in WSOC from the cold to the warm seasons (Fig. 2c). The temporal variations of major ion species $\left(\mathrm{SO}_{4}{ }^{2-}, \mathrm{Ca}^{2+}, \mathrm{K}^{+}\right.$, and $\mathrm{NO}_{\mathrm{X}}$ ) showed no such seasonality through a year (Fig. S4).

5

\subsection{Sources of WSOC}

In order to characterize the source of HULIS and WSOC in Seoul, which may cause seasonal variability, we analyzed various tracers including $\delta^{13} \mathrm{C}_{\mathrm{WSOC}}$ and major ions $\left(\mathrm{SO}_{4}{ }^{2-}, \mathrm{NO}_{\mathrm{X}}, \mathrm{K}^{+}\right.$, and $\mathrm{Ca}^{2+}$ ) as source indicators (Kirillova et al., 2014b; $\mathrm{Fu}$ et al., 2015; Kelly et al., 2005; Bosch et al., 2014; Gabriel et al., 2002; Dentener et al., 2006; Yan and Kim, 2015). A good correlation $\left(\mathrm{r}^{2}=0.6, \mathrm{p}>0.05\right)$ between WSOC and WSON concentrations suggests that these two variables are highly associated with a common organic source (Fig. 3a) (Yan and Kim, 2015). However, these two components are de-coupled from seasonal variations of marine sea-spray contribution based on $\mathrm{Cl}^{-}$and $\mathrm{Na}^{+}$concentrations $\left(\mathrm{r}^{2}=0.02, \mathrm{p}>0.1\right)$ (Maenhaut et al., 2008) and from the contribution of fossil fuel combustions based on $\mathrm{SO}_{4}{ }^{2-}$ and $\mathrm{NO}_{\mathrm{X}}$ concentrations $\left(\mathrm{r}^{2}=0.02, \mathrm{p}<0.05\right.$ and $\mathrm{r}^{2}=0.1, \mathrm{p}>0.01$, respectively) (Bosch et al., 2014; Gabriel et al., 2002; Dentener et al., 2006; Yan and Kim, 2015) in aerosols (Fig. 3b-3d). A correlation between WSOC and $\mathrm{K}^{+}\left(\mathrm{r}^{2}=0.3, \mathrm{p}<0.001\right)$ suggests that there is some influence of terrestrial sources or biomass burning in aerosols (Fig. 3d) (Baduel et al., 2010; Bosch et al., 2014; Gabriel et al., 2002). $\mathrm{K}^{+}$ to $\mathrm{Ca}^{2+}$ ratios were higher during the month of Mar-Apr and Nov indicating more significant influence of biomass burning source during these periods, while $\mathrm{K}^{+}$to $\mathrm{SO}_{4}{ }^{2-}$ maintained a constant ratio through a year (Fig. S5). The $\delta^{13} \mathrm{C}_{\mathrm{Wsoc}}$ values ranged from -21.0 to $-27.5 \%$ (mean $=-24.0 \pm 1.5 \%$ ) (Fig. $2 \mathrm{~d}$ ) and the yearlong average value ranged from -24.0 to $-26.0 \%$, suggesting that suspended terrestrial C3 plant-origin materials (Fu et al., 2015; Kelly et al., 2005) are the main sources of WSOC in this region. Evidence from previous studies indicates that relatively higher $\delta^{13} \mathrm{C}_{\mathrm{Wsoc}}$ values in spring and summer (Fig. 2d) may be associated with the Yellow dust inputs (Fig. 1) (Lin et al., 2012; Cao et al., 2005) and photochemical aging of aerosols (Bosch et al., 2014; Aggarwal and Kawamura, 2008), respectively.

Although the sources of WSOC and HULIS are complicated and vary over all seasons, a strong correlation $\left(\mathrm{r}^{2}=0.6, \mathrm{p}<\right.$ 0.001) was found between WSOC and HULIS (C1) (Fig. 4a), while WSON and HULIS exhibited a poor correlation $\left(\mathrm{r}^{2}=\right.$ $0.17, \mathrm{p}<0.001)$. Therefore, we examined whether or not a sink determines the seasonal variability of WSOC and HULIS. The HULIS fraction was greatly reduced during the warm season (Jun-Sep) when the solar UV radiation and temperature reached the annual maxima (Fig. $2 b$ and 2 e). A statistically significant negative correlation $\left(r^{2}=0.5, p<0.001\right)$ was observed between fluorescence intensity of HULIS and UV radiation (Fig. 4b). The seasonal-averaged fluorescence property of HULIS and the WSOC concentration were gradually reduced from the cold season (Oct-Jan) to the warm season (Jun-Sep) 
Atmos. Chem. Phys. Discuss., https://doi.org/10.5194/acp-2017-554

Manuscript under review for journal Atmos. Chem. Phys.

Discussion started: 5 July 2017

(c) Author(s) 2017. CC BY 4.0 License.

(c) (i)

by approximately $80 \%$ and $30 \%$, respectively, as the UV radiation rate increased from 8.5 to $19.4 \mathrm{MJ} \mathrm{m}^{-2}$ (Fig. S6). These trends indicate that intensity of solar UV radiation greatly contributed to the degree of photo-induced degradation of HULIS.

\subsection{Photochemical degradation of HULIS}

5 It has been widely accepted that photochemical degradation is an important process for the efficient removal of chromophoric dissolved organic matter (CDOM) that absorbs and fluoresces at certain wavelengths of light under solar radiation in aquatic ecosystems, which alters absorption in the UV region, spectral shape, and CDOM composition (Kim and Kim, 2016; Helms et al., 2013; Mladenov et al., 2009). The humic selective photochemical degradation of aerosol WSOC was resulted in greater reduction in the optical properties and WSOC content in total carbon pool (Birdwell and Engel, 2010; Helms et al., 2013). These results were in agreement to the laboratory experimental results.

After 6-week UV irradiation, the fluorescence intensity of HULIS and WSOC concentrations decreased by approximately $52 \%$ and $25 \%$, respectively, for the winter aerosol sample (Fig. 5a and Fig. S7). However, no significant changes in fluorescence or carbon contents occurred for the summer aerosol sample (Fig. 5b and Fig. S7). This suggests that the summer aerosol sample may consist largely of photo-refractory WSOC pool, while the winter aerosol sample consists largely of photo-labile WSOC. Photo-refractory residue in the summer aerosol sample might occur as aerosols, which are already photo-degraded on exposure to higher solar radiation intensity in the atmosphere. Consequently, the laboratory experiment results agree very well with the real-world monitoring results and confirmed that atmospheric HULIS is predominantly reduced by the photo-induced degradation.

The absorbance spectra of HULIS exhibited similar changes to fluorescence properties during the UV irradiation (Fig. S8). In order to evaluate the UV impacts on absorbance of HULIS and WSOC, a specific absorption values at $240 \mathrm{~nm}(a(240))$ and $350 \mathrm{~nm}(a(350))$ were compared with the integrated fluorescence signal of HULIS (Fig. S8). A significant correlation was found between the integrated fluorescence signal of HULIS and absorbance $a(240)\left(\mathrm{r}^{2}=0.98, \mathrm{p}<0.001\right)$ and $a(350)\left(\mathrm{r}^{2}\right.$

$=0.92, \mathrm{p}>0.02$ ), suggesting that absorbance and fluorescence properties are highly interrelated each other, which is consistent with previous studies (Green and Blough, 1994; Kieber et al., 2006; Mladenov et al., 2010; Santos et al., 2009), and HULIS and WSOC pool has reduced as a result of photochemical degradation. 
Atmos. Chem. Phys. Discuss., https://doi.org/10.5194/acp-2017-554

Manuscript under review for journal Atmos. Chem. Phys.

Discussion started: 5 July 2017

(c) Author(s) 2017. CC BY 4.0 License.

(c) (i)

\section{Conclusions}

Seasonal variations in fluorescence and chemical properties of HULIS and WSOC have been monitored over different seasons in urban region, Seoul. HULIS and WSOC were predominantly degraded by solar UV radiation approximately $80 \%$ and $30 \%$, respectively, during the warm seasons (Jun-Sep). Our results suggest that photo-induced degradation plays a significant role in HULIS abundances in the atmosphere and might be an important removal mechanism of the lightabsorbing organic aerosols. Although our research provides an important atmospheric process, more studies are required to quantify and constrain this process. Moreover, since atmospheric HULIS and BrC have a significant overlap in their lightabsorbing and chemical properties, this may provides important pieces regarding the life cycle of $\mathrm{BrC}$.

Light-absorbing organic aerosols and climate sensitivity are highly associated each other due to their significant role in radiative forcing and global climate balance. Our results show that such photochemical degradation needs to be included in modeling climate forcing, behavior of atmospheric organic matter, and biogeochemical cycles in Earth's surface in the future. Furthermore, deposition fluxes of organic aerosols with different optical characteristics can have a significant impact as a potential source of organic carbon to surface waters and, consequently, having major implications on global carbon cycle.

\section{Author Contributions}

G.Kim involved in planning the research and designing the experiment. H.Han collected the data and performed the analyses and experiment. G.Kim and H.Han involved in analyzing the results and writing the manuscript.

\section{Competing interests}

The authors declare no competing financial interests.

Acknowledgements. This work was supported by the National Research Foundation (NRF) of Korea (NRF2015R1A2A1A10054309) funded by the Korean government. We are grateful to Jeonghyun Kim and Shin-Ah Lee for their support and assistance. We also gratefully acknowledge the NOAA Air Resources Laboratory for use of the HYSPLIT model. 
Atmos. Chem. Phys. Discuss., https://doi.org/10.5194/acp-2017-554

Manuscript under review for journal Atmos. Chem. Phys.

Discussion started: 5 July 2017

(c) Author(s) 2017. CC BY 4.0 License.

(c) (i)

\section{References}

Aggarwal, S. G. and Kawamura, K.: Molecular distributions and stable carbon isotopic compositions of dicarboxylic acids and related compounds in aerosols from Sapporo, Japan: Implications for photochemical aging during long-range atmospheric transport, J. Geophys. Res., 113, D14301, doi:10.1029/2007JD009365, 2008.

Andreae, M. and Gelencsér, A.: Black carbon or brown carbon? The nature of light-absorbing carbonaceous aerosols, Atmos. Chem. Phys., 6, 3131-3148, 2006.

Baduel, C., Voisin, D., and Jaffrezo, J. L.: Seasonal variations of concentrations and optical properties of water soluble HULIS collected in urban environment, Atmos. Chem. Phys., 10, 4085-4095, 2010.

Birdwell, J. E. and Engel, A. S.: Characterization of dissolved organic matter in cave and spring waters using UV-Vis absorbance and fluorescence spectroscopy, Org. Geochem., 41, 270-280, 2010.

Bosch, C., Andersson, A., Kirillova, E. N., Budhavant, K., Tiwari, S., Praveen, P. S., Russell, L. M., Beres, N. D., Ramanathan, V., and Gustafsson, Ö.: Source-diagnostic dual-isotope composition and optical properties of watersoluble organic carbon and elemental carbon in the South Asian outflow intercepted over the Indian Ocean, J. Geophys. Res., 119, 11743-11759, doi:10.1002/2014JD022127, 2014.

Bro, R.: PARAFAC. Tutorial and applications, Chemometr. Intell. Lab., 38, 149-171, 1997.

Cao, J. J., Lee, S. C., Zhang, X. Y., Chow, J. C., An, Z. S., Ho, K. F., Watson, J. G., Fung, K., Wang, Y. Q., and Shen, Z. X.: Characterization of airborne carbonate over a site near Asian dust source regions during spring 2002 and its climatic and environmental significance, J. Geophys. Res., 110, D03203, doi:10.1029/2004JD005244, 2005.

Chen, Q., Ikemori, F., and Mochida, M.: Light absorption and excitation-emission fluorescence of urban organic aerosol components and their relationship to chemical structure, Environ. Sci. Technol., 50, 10859-10868, 2016.

Chun, Y., Boo, K. O., Kim, J., Park, S. U., and Lee, M.: Synopsis, transport, and physical characteristics of Asian dust in Korea, J. Geophys. Res., 106, D16, 18461-18469, 2001.

Coble, P. G.: Marine optical biogeochemistry: the chemistry of ocean color, Chem. Rev., 107, 402-418, 2007.

Dentener, F., Drevet, J., Lamarque, J. F., Bey, I., Eickhout, B., Fiore, A. M., Hauglustaine, D., Horowitz, L. W., Krol, M., Kulshrestha, U. C., Lawrence, M., Galy-Lacaux, C., Rast, S., Shindell, D., Stevenson, D., van Noije, T., Atherton, C., 
Atmos. Chem. Phys. Discuss., https://doi.org/10.5194/acp-2017-554

Manuscript under review for journal Atmos. Chem. Phys.

Discussion started: 5 July 2017

(c) Author(s) 2017. CC BY 4.0 License.

(c) (i)

Bell, N., Bergman, D., Butler, T., Cofala, J., Collins, B., Doherty, R., Ellingsen, K., Galloway, J., Gauss, M., Montanaro, V., Müller, J. F., Pitari, G., Rodriguez, J., Sanderson, M., Solmon, F., Strahan, S., Schultz, M., Sudo, K., Szopa, S., and Wild, O.: Nitrogen and sulfur deposition on regional and global scales: A multimodel evaluation, Global Biogeochem. Cy., 20, GB4003, doi:10.1029/2005GB002672, 2006.

5 Duarte, R. M. B. O. and Duarte, A. C.: Atmospheric organic matter, eMagRes., 2, 415-426, 2013.

Fu, P., Kawamura, K., Chen, J., Qin, M., Ren, L., Sun, Y., Wang, Z., Barrie, L. A., Tachibana, E., Ding, A., and Yamashita, Y.: Fluorescent water-soluble organic aerosols in the High Arctic atmosphere, Sci. Rep., 5, 9845, doi:10.1038/srep09845, 2015.

Gabriel, R., Mayol-Bracero, O. L., and Andreae, M. O.: Chemical characterization of submicron aerosol particles collected over the Indian Ocean, J. Geophys. Res., 107, 8005, 2002.

Ghan, S. J. and Schwartz, S. E.: Aerosol properties and processes: A path from field and laboratory measurements to global climate models, Amer. Meteor. Soc., 88, 1059-1083, 2007.

Graber, E. R. and Rudich, Y.: Atmospheric HULIS: How humic-like are they? A comprehensive and critical review, Atmos. Chem. Phys., 6, 729-735, 2006.

Green, S. A. and Blough, N. V.: Optical absorption and fluorescence properties of chromophoric dissolved organic matter in natural waters, Limnol. Oceanogr., 39, 1903-1916, 1994.

Gustafsson, Ö., Kruså, M., Zencak, Z., Sheesley, R. J., Granat, L., Engström, E., Praveen, P. S., Rao, P. S. P., Leck, C., and Rodhe, H.: Brown clouds over South Asia: biomass or fossil fuel combustion?, Science, 323, 495-498, doi:10.1126/science.1164857, 2009.

Helms, J. R., Stubbins, A., Perdue, E. M., Green, N. W., Chen, H., and Mopper, K.: Photochemical bleaching of oceanic dissolved organic matter and its effect on absorption spectral slope and fluorescence, Mar. Chem., 155, 81-91, 2013.

Hoffer, A., Gelencsér, A., Guyon, P., Kiss, G., Schmid, O., Frank, G. P., Artaxo, P., and Andreae, M. O.: Optical properties of humic-like substances (HULIS) in biomass-burning aerosols, Atmos. Chem. Phys., 6, 3563-3570, doi:10.5194/acp6-3563-2006, 2006. 
Atmos. Chem. Phys. Discuss., https://doi.org/10.5194/acp-2017-554

Manuscript under review for journal Atmos. Chem. Phys.

Discussion started: 5 July 2017

(c) Author(s) 2017. CC BY 4.0 License.

(c) (i)

Kanakidou, M., Seinfeld, J. H., Pandis, S. N., Barnes, I., Dentener, F. J., Facchini, M. C., Van Dingenen, R., Ervens, B., Nenes, A., Nielsen, C. J., Swietlicki, E., Putaud, J. P., Balkanski, Y., Fuzzi, S., Horth, J., Moortgat, G. K., Winterhalter, R., Myhre, C. E. L., Tsigaridis, K., Vignati, E., Stephanou, E. G., and Wilson, J.: Organic aerosol and global climate modeling: a review, Atmos. Chem. Phys., 5, 1053-1123, 2005.

5 Kelly, S. D., Stein, C., and Jickelle, T. D.: Carbon and nitrogen isotopic analysis of atmospheric organic matter, Atmos. Environ., 39, 6007-6011, 2005.

Kieber, R. J., Whitehead, R. F., Reid, S. N., Willey, J. D., and Seaton, P. J.: Chromophoric dissolved organic matter (CDOM) in rainwater, Southeastern North Carolina, USA, J. Atmos. Chem., 54, 21-41, 2006.

Kim, J. and Kim, G.: Significant anaerobic production of fluorescent dissolved organic matter in the deep East Sea (Sea of Japan), Geophys. Res. Lett., 43, 7609-7616, 2016.

Kim, T.-H., Kim, G., Lee, S.-A., and Dittmar, T.: Extraordinary slow degradation of dissolved organic carbon (DOC) in a cold marginal sea, Sci. Rep., 5, 13808, doi:10.1038/srep13808, 2015.

Kirillova, E. N., Andersson, A., Han, J., Lee, M., and Gustafsson, Ö.: Sources and light absorption of water-soluble organic carbon aerosols in the outflow from northern China, Atmos. Chem. Phys., 14, 1413-1422, 2014a.

Kirillova, E. N., Andersson, A., Tiwari, S., Sribastava, A. K., Bisht, D. S., and Gustafsson, Ö.: Water-soluble organic carbon aerosols during a fall New Delhi winter: Isotope-based source apportionment and optical properties, J. Geophys. Res. Atmos., 119, 3476-3485, doi:10.1002/2013JD020041, 2014b.

Kivácsy, Z., Kiss, G., Ceburnis, D., Jennings, G., Maenhaut, W., Salma, I., and Shooter, D.: Study of water-soluble atmospheric humic matter in urban and marine environments, Atmos. Rea., 87, 1-12, 2008.

Lawaetz, A. J. and Stedmon, C. A.: Fluorescence intensity calibration using the raman scatter peak of water, Appl. Spectrosc., 63, 936-940, 2009.

Lin, C. Y., Sheng, Y. F., Chen, W. N., Wang, Z., Kuo, C. H., Chen, W. C., and Yang, T.: The impact of channel effect on Asian dust transport dynamics: a case in southeastern Asia, Atmos. Chem. Phys., 12, 271-285, doi:10.5194/acp-12271-2012, 2012. 
Maenhaut, W. Raes, N., Chi, X., Cafmeyer, J., and Wang, W.: Chemical composition and mass closure for $\mathrm{PM}_{2.5}$ and $\mathrm{PM}_{10}$ aerosols at K-puszta, Hungary, in summer 2006, X-RAY Spectrom., 37, 193-197, 2008.

Matos, J. T. V., Freire, S. M. S. C., Duarte, R. M. B. O., and Duarte, A. C.: Natural organic matter in urban aerosols: comparison between water and alkaline soluble components using excitation-emission matrix fluorescence spectroscopy and multiway data analysis, Atmos. Environ., 102, 1-10, 2015.

Mladenov, N., Lopez-Ramos, J., McKnight, D. M., and Reche, I.: Alpine lake optical properties as sentinels of dust deposition and global change, Limnol. Oceanogr., 54, 6-2, 2386-2400, 2009.

Mladenov, N., Sommaruga, R., Morales-Baquero, R., Laurion, I., Camarero, L., Diéguez, M. C., Camacho, A., Delgado, A., Torres, O., Chen, Z., Felip, M., and Reche, I.: Dust inputs and bacteria influence dissolved organic matter in clear alpine lakes, Nat. Commun., 2, 405, doi:10.1038/ncomms1411, 2011.

Panetta, R. J., Ibrahim, M., and Gélinas, Y.: Coupling a high-temperature catalytic oxidation total organic carbon analyzer to an isotope ratio mass spectrometer to measure natural-abundance $\delta^{13} \mathrm{C}$-dissolved organic carbon in marine and freshwater samples, Anal. Chem., 80, 5232-5239, 2008.

Pöhlker, C., Huffman, J. A., Pöschl, U.: Autofluorescence of atmospheric bioaerosols - fluorescent biomolecules and potential interferences, Atmos. Meas. Tech., 5, 37-71, 2012.

Ramanathan, V., Ramana, M. V., Roberts, G., Kim, D., Corrigan, C., Chung, C., and Winker, D.: Warming trends in Asia amplified by brown cloud solar absorption, Nature, 448, 575-578, doi:10.1038/nature06019, 2007.

Saleh, R., Robinson, E. S., Tkacik, D. S., Ahern, A. T., Liu, S., Aiker, A. C., Sullivan, R. C., Presto, A. A., Dubey, M. K., Yokelson, R. J., Donahue, N. M., and Robinson, A. L.: Brownness of organics in aerosols from biomass burning linked to their black carbon content, Nat. Geosci., 7, 36940, doi:10.1038/ngeo2220, 2014.

Stedmon, C. A. and Bro, R.: Characterizing dissolved organic matter fluorescence with parallel factory analysis: a tutorial, Limnol. Oceanogr. Meth., 6, 11, 572-579, 2008.

Stedmon, C. A. and Markager, S.: Resolving the variability in dissolved organic matter fluorescence in a temperate estuary and its catchment using PARAFAC analysis, Limnol. Oceanogr., 50, 686-697, 2005. 
Atmos. Chem. Phys. Discuss., https://doi.org/10.5194/acp-2017-554

Manuscript under review for journal Atmos. Chem. Phys.

Discussion started: 5 July 2017

(c) Author(s) 2017. CC BY 4.0 License.

(c) (i)

Stein, A. F., Draxler, R. R., Rolph, G. D., Stunder, B. J. B., Cohen, M. D., and Ngan, F.: NOAA's HYSPLIT atmospheric transport and dispersion modeling system, Amer. Meteor. Soc., 96, 2059-2077, 2015.

Troyer, I. D., Bouillon, S., Barker, S., Perry, C., Coorevits, K., and Merckx, R.: Stable isotope analysis of dissolved organic carbon in soil solutions using a catalytic combustion total organic carbon analyzer-isotope ratio mass spectrometer with a cryofocusing interface, Rapid Commun. Mass Spectrom., 24, 365-374, 2010.

Velapoldi, R. A. and Mielenz, K. D.: Standard reference materials: a fluorescence standard reference material: quinine sulfate dehydrate, National Bureau of Standards Special Publication 260-64, US Government Printing Office, 1980.

Wozniak, A. S., Bauer, J. E., and Dickhut, R. B.: Characteristics of water-soluble organic carbon associated with aerosol particles in the eastern United States, Atmos. Environ., 46, 181-188, 2012.

Xie, M., Mladenov, N., Williams, M. W., Neff, J. C., Wasswa, J., and Hannigan, M. P.: Water soluble organic aerosols in the Colorado Rocky Mountains, USA: composition, sources and optical properties, Sci. Rep., 6, 39339, doi:10.1038/srep39339, 2016.

Yan, G. and Kim, G.: Sources and fluxes of organic nitrogen in precipitation over the southern East Sea/Sea of Japan, Atmos. Chem. Phys., 15, 2761-2774, 2015.

Zepp, R. G., Sheldon, W. M., and Moran, M. A.: Dissolved organic fluorophores in southeastern US coastal waters: correction method for eliminating Rayleigh and Raman scattering peaks in excitation-emission matrices, Mar. Chem., $89,15-36,2004$ 
Atmos. Chem. Phys. Discuss., https://doi.org/10.5194/acp-2017-554

Manuscript under review for journal Atmos. Chem. Phys.

Discussion started: 5 July 2017

(c) Author(s) 2017. CC BY 4.0 License.

\section{Atmospheric \\ Chemistry \\ and Physics \\ Discussions}

5

10

15

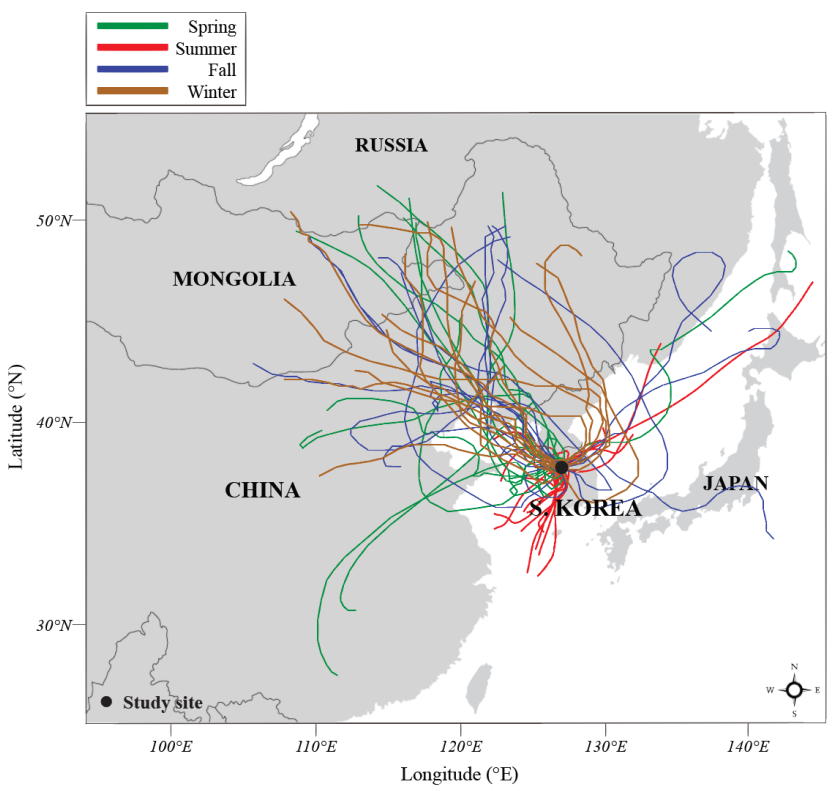

Figure 1: Map of the geographical region around the study site and air mass transport pathways over different seasons: spring (green), summer (red), fall (blue), and winter (brown). A 10-day air mass back trajectory was drawn using HYSPLIT model from March 2015 to January 2016 in Seoul. 
Atmos. Chem. Phys. Discuss., https://doi.org/10.5194/acp-2017-554

Manuscript under review for journal Atmos. Chem. Phys.

Discussion started: 5 July 2017

(c) Author(s) 2017. CC BY 4.0 License.
Atmospheric

Chemistry

and Physics

Discussions
5

10

15
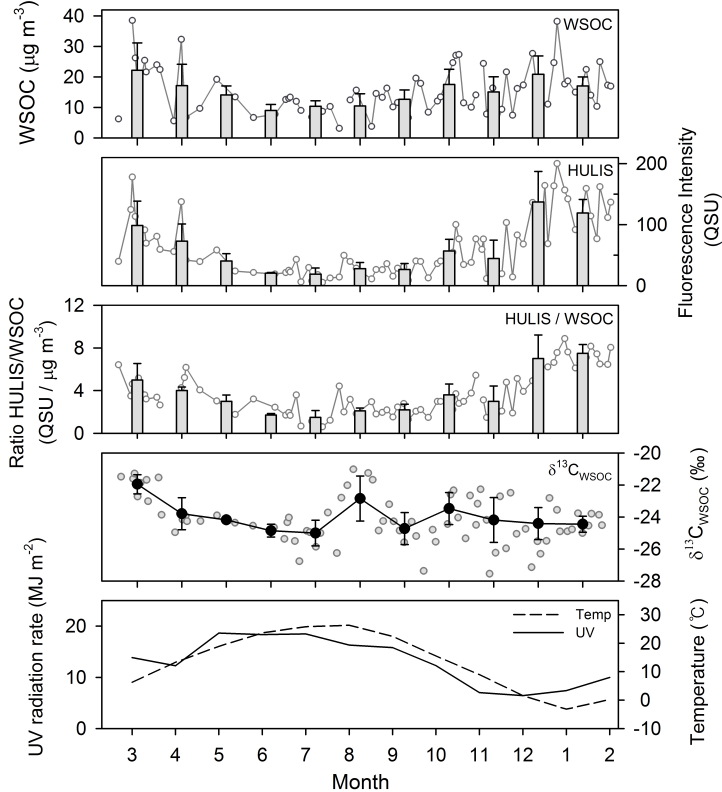

Figure 2: Temporal variations of (a) WSOC concentration, (b) fluorescence intensity of HULIS (C1), (c) ratio of fluorescence intensity of HULIS (C1) to WSOC concentration, (d) $\delta^{13} C_{W S O C}$, and (e) UV radiation rate and temperature from March 2015 to January 2016 in Seoul. Error bars represent the standard deviation for each parameter. Bars represent monthly averaged values and line plots represent single value of each aerosol sample. 
Atmos. Chem. Phys. Discuss., https://doi.org/10.5194/acp-2017-554

Manuscript under review for journal Atmos. Chem. Phys.

Discussion started: 5 July 2017

(c) Author(s) 2017. CC BY 4.0 License.

(c) (1)

5

10

15

Figure 3: Correlations between concentrations of (a) WSOC and WSON $\left(r^{2}=0.6, p>0.05\right)$, (b) WSOC and sea-spray $\left(r^{2}=0.02, p\right.$ $>0.01$ ), (c) WSOC and $\mathrm{NO}_{\mathrm{X}}$ (open circle; $\left.\mathrm{r}^{2}=0.1, \mathrm{p}>0.01\right)$ and $\mathrm{SO}_{4}{ }^{2-}$ (closed circle; $\mathrm{r}^{2}=0.02, \mathrm{p}<0.05$ ), and (d) WSOC and $\mathrm{Ca}^{2+}$ (open circle; $\left.\mathrm{r}^{2}=0.1, \mathrm{p}<0.01\right)$ and $\mathrm{K}^{+}\left(\right.$closed circle; $\left.\mathrm{r}^{2}=0.3, \mathrm{p}<0.01\right)$. Solid lines indicate the regression line.
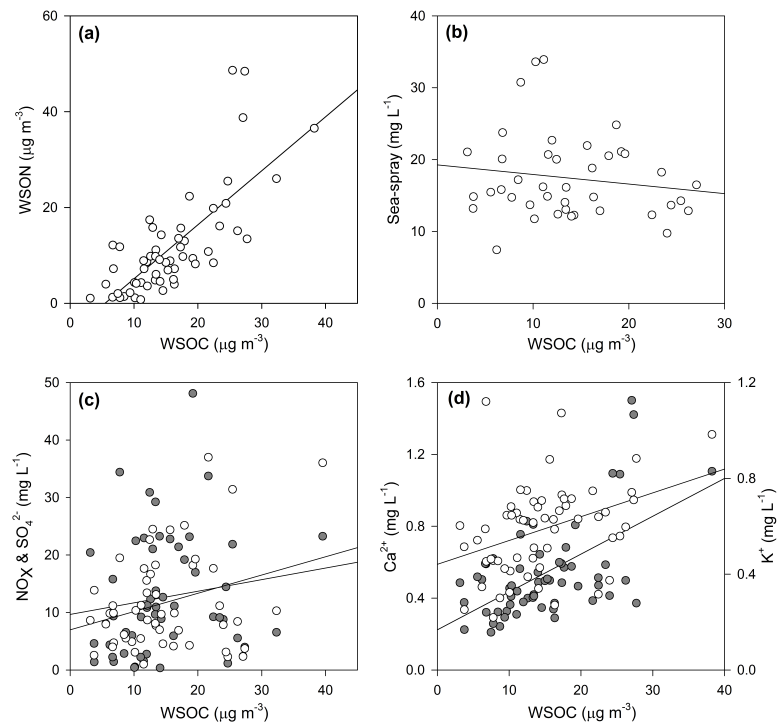
Atmos. Chem. Phys. Discuss., https://doi.org/10.5194/acp-2017-554

Manuscript under review for journal Atmos. Chem. Phys.

Discussion started: 5 July 2017

(c) Author(s) 2017. CC BY 4.0 License.

(c) (i)

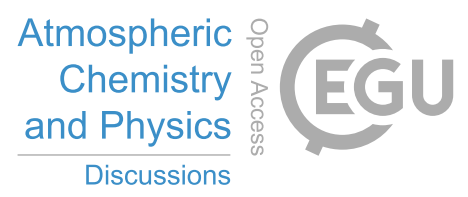

5

10
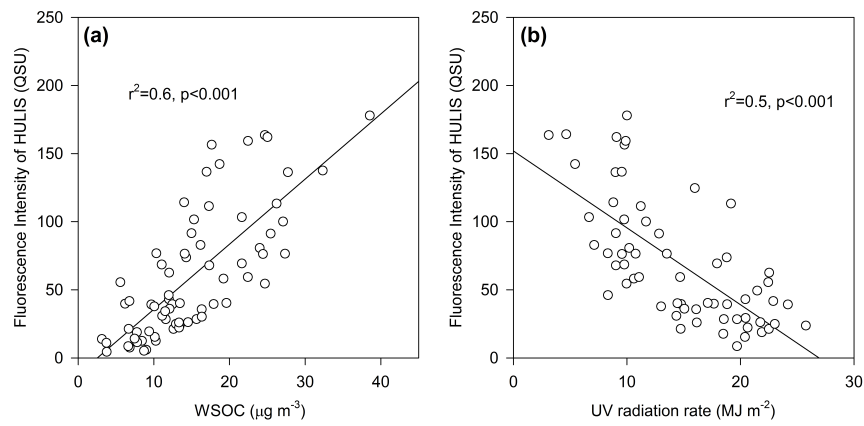

15

Figure 4: Linear correlations between (a) WSOC concentration and fluorescence intensity of HULIS (C1) and between (b) UV radiation rate and fluorescence intensity of HULIS (C1). Solid lines indicate the regression line. 
Atmos. Chem. Phys. Discuss., https://doi.org/10.5194/acp-2017-554

Manuscript under review for journal Atmos. Chem. Phys.

Discussion started: 5 July 2017

(c) Author(s) 2017. CC BY 4.0 License.

(c) (i)
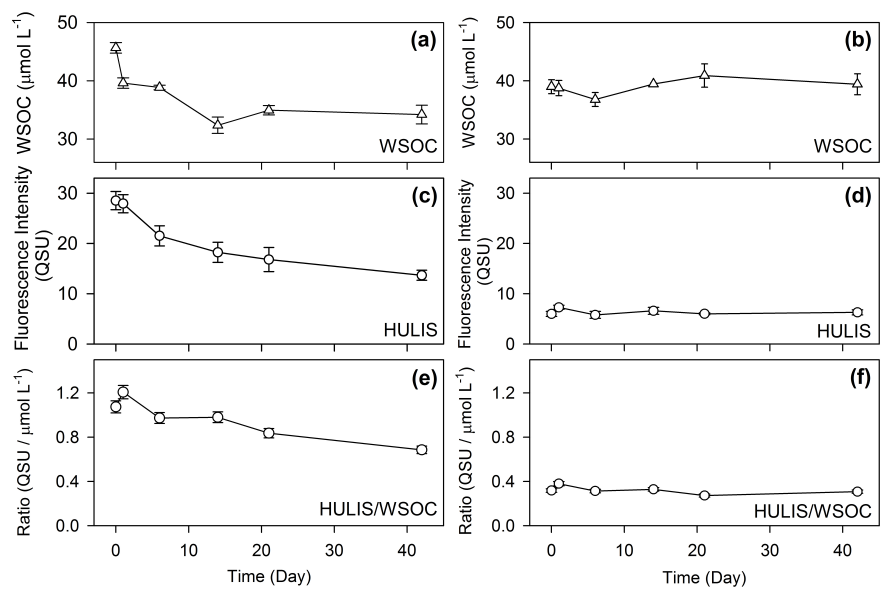

Figure 5: The WSOC concentration of the (a) winter and the (b) summer aerosol samples, fluorescence intensity of HULIS of the (c) winter and the (d) summer aerosol samples, and ratio of fluorescence intensity to WSOC concentration of the (e) winter and the (f) summer aerosol samples during laboratory experiment. Error bars represent the standard deviation for each parameter. 